\title{
Rättvisa i fördelning av sociala resurser: En socialpsykologisk forskningsöversikt
}

\section{ALI KAZEMI \& LARS-OLOF JOHANSSON}

Rättvisefrågor har diskuterats sedan Platon och Sokrates. Men till skillnad frän områdets normativa framtoning $i$ filosofiska kretsar, är socialpsykologerna intresserade av att studera människors subjektiva upplevelser av (o) rättvisa. Fokus ligger därför på förståelse och kartläggning av orsaker till och effekter av upplevd (o) rättvisa i olika sammanhang. I denna artikel ges en forskningsöversikt över området. Artikeln avslutas med en kort diskussion om vad den socialpsykologiska rättviseforskningen kan tillföra $i$ fråga om förståelse av social problematik.

\section{Inledning}

Människan har ett grundläggande behov av rättvisa. Åtskilliga studier visar att individen reagerar på en rad olika sätt när detta

Ali Kazemi, fil.dr i psykologi, universitetslektor i socialpsykologi, Högskolan i Skövde

Lars-Olof Johansson, fil.dr i psykologi, Psykologiska institutionen, Göteborgs universitet behov inte tillgodoses (för systematiska översikter se Greenberg 1990 och Törnblom 1992). De lagar och regler som finns i mänskliga samhällen syftar till att upprätthålla ordning och skydda samhällets medborgare mot olika former av orättvisa.

Men vad är rättvisa egentligen? Dessvärre finns det inget enkelt svar på denna fråga. Som det kommer att framgå av denna artikel är rättvisa ett mångfacette- 
rat begrepp som kan definieras och uppfattas på många olika sätt. Upplevd orättvisa hänger ofta samman med individens rättviseuppfattningar i personliga eller samhälleliga frågor. Detta beror dels på att man tänker på olika aspekter av rättvisa, dels på att vår kulturella, sociala och ekonomiska bakgrund i stor utsträckning avgör vad som tillmäts störst betydelse. Perspektiv är således ett nyckelord i fråga om rättvisebedömningar. Det som en människa upplever som rättvist kan en annan uppleva som orättvist. Personer i privilegierad ställning försvarar sig till exempel ofta genom att hänvisa till sina förmågor eller till de viktiga funktioner man anser sig fylla i sin grupp eller i samhället vilket då föranleder att man anser sig förtjäna en större del av kollektiva resurser. De mindre bemedlade hänvisar å andra sidan ofta till att de saknar resurser för att kunna bidra till kollektivets intressen och uppfattar därför många gånger ett system som premierar prestationer och personliga talanger som mycket orättvist. Tvärkulturell rättviseforskning visar också på stora skillnader i rättviseuppfattningar och rättvist beteende mellan människor (t.ex. Morris \& Leung 2000).

Trots tvärkulturella skillnader i rättviseuppfattningar, visar viss forskning att rättvisa är ett universellt begrepp och därmed ett primärt behov, inte bara hos mänskliga, utan även bland många andra levande varelser. Till exempel visade Brosnan och de Waal (2003) i en rad studier att capuchinapor som sett en försöksdeltagare dela ut en större belöning till en annan apa för samma grad av ansträngning avböjde en ojämlik (orättvis) belöning och vägrade att samspela med försöksledaren. Det mänskliga perspektivet på rättvisa är dock mycket mer utvecklat och nyanserat och inte lika styrt av ett primitivt egocentriskt tänkande. Vuxna människor bryr sig till exempel om vad andra människor får i förhållande till varandra (Johansson \& Svedsäter, under tryckning) med avseende på hur mycket var och en har investerat, hur stort behov var och en har, och söker också upprätthålla ett rättvist system baserat på en rad olika universella moraliska principer såsom rätten till jämlik behandling.

Denna artikel är strukturerad enligt följande. Vi börjar med att diskutera ett antal teoretiska utgångspunkter för modern socialpsykologisk rättviseforskning. Därefter behandlas teori och forskning som berör fördelnings- och procedurrättvisa ingående. Vi tar även upp forskning om individuella skillnader i rättviseuppfattningar. Artikeln avslutas med en summering och en kort behandling av viktiga trender, kontroversiella ämnen och forskningsmetoder inom socialpsykologisk rättviseforskning. Avslutningsvis berörs även forskningsfältets relevans för socialt arbete.

\section{Socialpsykologisk teori och forskning om rättvisa}

Två huvudsakliga ansatser kan urskiljas vid studier av rättvisa: den normativa och den deskriptiva. Den normativa ansatsen innebär att rättvisa betraktas $i$ absoluta termer med påbud och förbud (vad som bör respektive inte får göras). Denna ansats är vanligast inom filosofi och religion. Den deskriptiva (beskrivande) ansatsen som anammas inom socialpsykologi fokuserar 
däremot hur människor uppfattar rättvisa. Utifrån en sådan ansats studerar forskare bland annat faktorer som påverkar våra rättviseuppfattningar och konsekvenser av (o)rättvis behandling eller fördelning (för en genomgång av forskningsfrågor inom den deskriptiva ansatsen se Kazemi \& Törnblom 2008).

Diskussioner kring rättvisa har ett långt förflutet, men en mer systematisk rättviseforskning inom socialpsykologin har inte mer än dryga fyrtio år på nacken. Det började inom socialpsykologin med Stacy Adams formulering av teorin om proportionell fördelning (Adams 1965). Denna ensidiga inriktning på proportionell fördelning som den enda rättvisa fördelningsprincipen kom senare att ifrågasättas. Man började istället tänka i termer av multipla fördelningsprinciper (behov, jämlikhet och förtjänst) vilket fick till följd att forskningen under en tid var fokuserad på kartläggning av faktorer som skulle vara vägledande för val av fördelningsprincip. Forskningen om fördelningsrättvisa dominerade fältet under 1960- och 1970-talen. Forskarna började senare intressera sig även för hur fördelningsbeslut fattas, vilket vi nedan behandlar under rubriken procedurrättvisa. Under 1980- och 1990-talen har denna forskningsinriktning varit dominerande och ett antal teorier har lanserats kring procedurrättvisans betydelse. Det senaste decenniet har vi sett ett antal försök till integrering av forskning kring fördelningsoch procedurrättvisa (för en genomgång se Kazemi \& Törnblom 2008). Dessutom har man börjat intressera sig för andra dimensioner i rättvisebegreppet än bara de som rör fördelning och procedur. Som exempel kan interpersonell rättvisa nämnas som rör den kommunikativa aspekten (t.ex. respekt och ärlighet) i mellanmänskliga relationer. Vi återkommer till detta senare i artikeln.

\section{Viktiga utgångspunkter}

Detta avsnitt ägnas åt en genomgång av några viktiga teoretiska utgångspunkter som kan sägas utgöra rötterna till modern socialpsykologisk rättviseforskning. Den första utgångspunkten är att människan är en social varelse. En viktig komponent i vår socialitet är att vi jämför oss själva med andra som vi upplever är lika oss i olika avseenden. Detta är självklart men, som vi kommer att se senare, ändå av central betydelse för att förstå uppkomsten och upplevelser av orättvisa. Enligt teorin om sociala jämförelser (Festinger 1954) får vi en uppfattning om våra förmågor och förstår vad vi tycker i olika frågor genom att jämföra oss med andra. Sociala jämförelser är vanligast när det råder osäkerhet och när det inte finns några objektiva riktlinjer. Vidare menar Festinger att vi jämför oss med dem som är lika oss i vissa för oss viktiga hänseenden.

Vi har, som sociala varelser, ett behov av att tillhöra/ingå i olika grupper. I dessa grupper jämför vi oss med andra oavsett om vi faktiskt tillhör eller strävar efter att tillhöra gruppen. Dessa sociala jämförelser resulterar i antingen positiva eller negativa utfall. Positiva utfall kan handla om tillfredsställelse eller rättvisa, och negativa utfall kan handla om det omvända. Viktigt att notera är att det inte är objektiva fakta eller faktiska förhållanden som avgör 
om utfallet är negativt eller positivt utan individens subjektiva upplevelser som styr nivån av tillfredsställelse. Enligt teorin om relativ deprivation (Stouffer et al. 1949) är individens känsla av att vara berövad viktiga resurser inte absolut utan beroende av just relativa jämförelser. Den individ som saknar något känner sig berövad och förbittrad, enligt denna teori, endast om följande villkor är uppfyllda: (1) någon annan har X (den aktuella resursen), (2) individen önskar ha X, (3) individen känner sig berättigad till X, (4) individen anser att det är möjligt att ha X, (5) individen känner sig inte ansvarig för avsaknad av X (Crosby 1976).

En annan viktig utgångspunkt är att människan är involverad i en rad olika utbyten i egenskap av sin socialitet vilket är den centrala tesen i teorin om socialt utbyte (Homans 1961). Enligt denna teori handlar all mänsklig social interaktion om givande och tagande av resurser och följer vissa principer. Till exempel menar Homans att människan engagerar sig i belönande beteenden och ett beteende som följs av en belöning ökar sannolikheten för att beteendet skall upprepas. Homans såg människan som en kalkylerande och rationell varelse. Människan tänker, enligt honom, i termer av intäkter och utgifter och väljer det alternativ som maximerar de egna utfallen. Teorin om socialt utbyte hade stark påverkan på Stacy Adams teori om proportionell fördelning. Men, i motsats till Homans menade Adams att allt utbyte inbegriper rättvisebedömningar och inte enbart vinstmaximering. Enligt Adams strävar människan efter jämvikt i sina sociala utbyten. Ett utbyte är i jämvikt och därmed rättvist om belö- ningarna (utfallen) står i proportion till de bidrag som var och en i en grupp har gjort. Satsar man mer skall man också få mer samtidigt som detta skall stå i proportion till den andres insats och utfall. Mer om detta följer i avsnittet om fördelningsrättvisa.

Slutligen, en utgångspunkt som har varit mer undanskymd inom socialpsykologisk rättviseforskning är resursteorin (Foa 1971) som hävdar att utbyten omfattar olika typer av resurser. Uriel Foa (1971, se även Foa \& Foa 1976) kallar allt som kan överföras från en individ till en annan, från en grupp till en annan, eller mellan olika samhällen/stater för resurser. Han har utvecklat en typologi bestående av sex olika resursklasser (kärlek, status, information, pengar, varor och tjänster) längs två dimensioner. ${ }^{1}$ Den första dimensionen som han kallar partikularism handlar om i vilken utsträckning värdet av en given resurs påverkas av givarens identitet samt dennes relation till mottagaren. Ta till exempel pengar som är en universalistisk (motsatsen till parti-

1 Kärlek syftar på att man ger uttryck för tillgivenhet, värme eller välbefinnande. Status innebär att man gör en värderande bedömning som förmedlar prestige, hänsyn eller aktning. Information inkluderar råd, åsikter, instruktioner, eller upplysningar men exkluderar de beteenden som kan klassificeras som kärlek eller status. Pengar är mynt, sedlar eller andra standardenheter som har ett utbytesvärde. Varor är konkreta produkter, objekt eller material. Tjänster innebär aktiviteter som påverkar kroppen eller tillhörigheter till en person och innebär oftast arbete för någon annan. Uppdelningen av de sex resursklasserna har gjorts utifrån attributen abstrakt-konkret och partikularism- universalism. 
kularistisk) resurs. Det innebär att en viss mängd pengar är lika mycket värd oavsett vem vi får det ifrån, men samma förhållande gäller inte för kärlek som är en partikularistisk resurs. Utbyte av tjänster och saker omfattar konkreta aktiviteter, medan utbyte av status och information sker oftast med mer symboliska eller abstrakta verbala beteenden. Kärlek och pengar utbyts i såväl symboliska som konkreta former. Därför tar dessa en mittenposition i diagrammet.

Foa och Foa (1976) identifierade och föreslog ett antal utbytesprinciper för de olika resursklasserna utifrån deras position i diagrammet. Till exempel menar Foa att ju mer av våra pengar som vi ger till en annan individ, desto mindre blir det kvar till oss själva. Det samma förhållande gäller emellertid inte för kärlek och andra mer partikularistiska resurser. En annan regel med relevans för rättviseforskningen är regeln om identiskt resursbyte. Alltså vilka resurser som ges och fås i retur är viktigt. Mera specifikt innebär detta att ju mer partikularistisk en resurs är, desto större är sannolikheten (samt förväntningen) att den utbyts med samma resurs. Skulle så inte ske, kommer en restkänsla (eng. "residue», ett dissonanstillstånd som producerar obehag) att infinna sig hos individen. Ett exempel är att ge monetärt skadestånd till våldtäktsoffer för förlorad heder.

\section{Fördelningsrättvisa}

Socialpsykologers intresse för rättvisa började med Stacy Adams formulering av teorin om proportionell fördelning (eng. "equity“, Adams 1965). Adams var påver- kad av tre huvudsakliga teorier som vi redan har stiftat bekantskap med, nämligen Stouffer med fleras teori om relativ deprivation (Stouffer et al. 1949), psykologen Leon Festingers teori om sociala jämförelser (Festinger 1954) och sociologen George C. Homans teori om socialt utbyte (Homans 1961). För Adams var rättvisa lika med en tillämpning av proportionalitetsprincipen (kallas även merit- eller förtjänstprincipen). Sådan rättvisa råder när det finns en jämvikt mellan individens insatser (till exempel förmåga, ansträngning, prestation) och det individen får tillbaka på sin investering. Enligt Adams krävs också jämvikt mellan individens egen insats/utfall kvot och andras insats/utfall kvot för att rättvisa ska kunna sägas råda. Ett grundläggande antagande i teorin om proportionell fördelning är att upplevelser av orättvisa skapar kognitiv dissonans, ett tillstånd som kännetecknas av spänning och obehag, vilket individen i möjligaste mån söker undvika och eliminera. Det följer av detta antagande att såväl de som skapar orättvisa som de som drabbas av det söker rättfärdiga respektive kompensera orättvisan. Återställandet av rättvisa markerar individens strävan efter jämvikt. Men människans strävan efter rättvisa sammanhänger, enligt equity-teoretiker (Adams 1965, Walster et al. 1973, Walster et al. 1978), också med: (1) individens strävan efter belöningar (rättvisa belönas); (2) en positiv självvärdering; (3) ökad kontroll i meningen att individen med hjälp av denna rättvisenorm kan förutsäga resultatet av eget och andras handlande; och (4) en önskan att vidmakthålla tron på en rättvis värld där människor får vad de förtjänar (jfr. Lerner 1980). 
Teorin om proportionell fördelning har fått stark kritik (Deutsch 1975, Leventhal 1976, 1980, Mikula 1980). Kritikerna menar bland annat att vad som utgör individens insats i en specifik situation kan variera. Bör vi till exempel premiera talang, eller belöna efter prestation eller grad av ansträngning? Om vi fördelar samhällets resurser efter medfödd talang, kommer många att hamna utanför välfärdssystemet. Inom skolans värld, skall lärarna sätta betyg efter elevens ansträngningar eller efter faktisk prestation? En elev kan ha lagt ner hundra timmar på läsning inför ett prov och ändå prestera sämre än en annan som lagt ner bara tio timmar. Vad som bör vara det vägledande insatskriteriet är sällan självklart. En annan kritik har att göra med att rättvisefrågor inte är begränsade till en ekonomisk sfär där insats och utfall är i fokus. Med andra ord kan meritprincipen, som ofta tillämpas i ekonomiska och/eller formella relationer (till exempel på arbetet där lön sätts efter individuella meriter), lätt komma att skada relationerna inom en familj där föräldrarna i så fall skulle tycka bättre om de barn som hjälper till mer med hushållssysslorna. Forskarna brukar därför tala om ytterligare två huvudprinciper för resursfördelning, jämlikhetsprincipen som förser alla med en lika stor del av resursen oavsett skillnader i insatser eller meriter och behovsprincipen som fördelar resursen i förhållande till individuella behov (jämför med den marxistiska devisen som säger åt var och en efter behov, av var och en efter förmåga).

En fråga som vi nu kan ställa oss är varför rättvisa ibland definieras och tillämpas i enlighet med en princip och ibland i enlig- het med andra. Törnblom (1992) tillhandahåller en systematisk översikt av faktorer som påverkar val av fördelningsprincip. Han delar in faktorerna i sex huvudskaliga klasser: aktör, bidrag/insatser, social relation, fördelningsmål, kulturell kontext och resurser. Vi kommer i det följande att ge läsaren en inblick i de mest väsentliga faktorerna under varje klass. Det följande bygger i huvudsak på Törnblom (1992). I de fall där andra källor har använts anger vi referensen.

Aktörer i forskning om resursfördelning har varit individer eller grupper. Beroende på forskningsparadigm har försöksdeltagarna/respondenterna agerat antingen $\mathrm{i}$ rollen som mottagare, allokerare (det vill säga den som fördelar resursen till andra), eller båda. Könsskillnader har funnits i huvudsak i studier där försöksdeltagarna har varit såväl mottagare som allokerare av en viss resurs. I tävlingsinriktade gruppuppgifter har man sett att kvinnor fördelar resurser mera jämlikt än männen, medan männen fördelar i enlighet med meritprincipen (till exempel med avseende på skillnader i status så att de som har en högre status i gruppen tilldelas en större del av den kollektiva resursen). I konkurrensfria situationer finns det inga dokumenterade könsskillnader och då fördelas resursen enligt jämlikhetsprincipen. Man har även studerat betydelsen av ålder för rättviseuppfattningar. Forskningen visar att yngre barn upp till sexårsåldern tänker utifrån egenintresse och jämlikhetsprincipen. Detta beror delvis på att tillämpning av merit- och behovsprinciperna kräver en högre grad av moralisk och intellektuell förmåga. Andra faktorer vars betydelse har 
studerats, som vi av utrymmesskäl inte tar upp här, är yrke, inkomst, utbildning, politisk tillhörighet, och en rad olika stabila personlighetsrelaterade variabler (t.ex. Biel et al. 1997, Törnblom 1992 se även avsnittet "Individuella skillnader i rättviseuppfattningarı i denna artikel).

Insatser eller bidrag handlar om huruvida individens investering i olika kollektiva resurser görs frivilligt och genom ett aktivt val eller inte. Kollektiva resurser (med undantag av vissa naturresurser) kommer till stånd genom individuella bidrag. Till exempel finansieras vård och omsorg $i$ vårt samhälle av skattemedel. Det åligger alla medborgare att betala skatt på sin inkomst. Mycket förenklat skulle vi kunna säga att ju mer man tjänar desto mer förväntas man betala i skatt. En relaterad fråga är vad vi anser vara en rättvis fördelning av kollektiva nyttigheter i samhället. Skall till exempel den medborgare som betalat en högre skatt ges förtur eller särbehandlas inom vården? Eller tycker vi att resurser inom vården skall fördelas utefter de sökandes behov? Eller jämlikt? Forskningen visar att människor tycker att det är rättvist att fördela en kollektiv nyttighet i enlighet med meritprincipen endast om investeringen har gjorts frivilligt och genom ett aktivt val. Om så inte är fallet föredras jämlika fördelningar.

En annan betydelsefull faktor för val av fördelningssätt är den sociala relation $\mathrm{i}$ vilken en resurs fördelas. Generellt visar studier att jämlikhetsprincipen tillämpas och anses vara mest rättvis i samarbetsbetonade relationer då den förväntas skapa harmoni och stärka gruppsammanhållningen. I relationer som har en mer formell karaktär där status och prestation betonas tillämpas meritprincipen. Två andra aspekter har också beaktats inom forskningen, nämligen relationslängd och förväntning om framtida interaktion. Ju längre relationen har existerat och ju mer man förväntar sig en relation med andra i framtiden, desto mer benägen är man att låta resurser fördelas jämlikt.

En annan faktor som är närbesläktad med den föregående faktorn är fördelningsmål. Grupper hålls samman av olika typer av kollektiva mål. Kazemi och Eek (2008) utgick från att det $\mathrm{i}$ huvudsak finns tre typer av kollektiva mål: produktivitet eller prestationsorientering, harmoni eller relationsorientering, och socialt ansvar eller omsorgsorientering. Samtliga mål är viktiga för att grupper skall överleva och vara framgångsrika. Beroende på gruppens utvecklingsfas eller den specifika situation som gruppen möter dominerar vanligtvis ett mål över de övriga. Ny forskning har visat att prestationsorienterade grupper vanligen fördelar den gemensamma resursen $i$ enlighet med meritprincipen medan relationsorienterade grupper föredrar jämlika fördelningar och omsorgsorienterade grupper anser att behovsbaserade fördelningar är bättre (Kazemi \& Eek 2008). Dessa resultat kan till exempel hjälpa oss förstå varför medborgarna anser att samhällsresurser bör fördelas på olika sätt beroende på om dessa har producerats i privat eller statlig/kommunal regi. Förklaringen är att olika kollektiva mål är relaterade till olika värderingar. Till exempel förknippas den privata sektorn med effektivitet, konkurrens, och vinstmaximering, medan den offentliga sektorn förknippas med solidaritet, socialt ansvar, och omhändertagande. 
Troligen påverkar därför de avregleringar som genomförts i Sverige sedan 1990-talets mitt inom ett flertal områden (t.ex. el- och telemarknaden, skola och barnomsorg) våra fördelningspreferenser och rättviseuppfattningar.

Den kulturella/sociala kontexten $\mathrm{i}$ vilken resursfördelning sker har i ett flertal studier visats påverka fördelningsrättvisa. Törnblom et al. (1985) fann att svenskar ansåg jämlikhetsprincipen vara mer rättvis än amerikaner vilka i sin tur betraktade meritprincipen som mer rättvis än svenskarna. Lane (1986) argumenterade för att meritprincipen råder på marknaden (eller inom den privata sektorn), medan jämlikhet och behov är de principer som ses som rättvisa i den offentliga sfären. Det har också föreslagits att behovsprincipen anses vara mer rättvis i samhällen som är teknologiskt eftersatta eller har knappa resurser.

Vi avslutar detta avsnitt med att nämna något om betydelsen av sociala resurser för uppfattningar om fördelningsrättvisa. Tre egenskaper hos sociala resurser är relevanta i diskussionen om fördelningsrättvisa, nämligen resurstyp (Uriel Foa's resursteori med sex resursklasser), resursmängd (handlar om huruvida resursen finns i överflöd eller om den är knapp) och resursvalens (handlar om det är en vinst/ett överskott eller en förlust/ett underskott som skall fördelas).

Resurser i Foa's teori har olika egenskaper vilket innebär att en fördelningsprincip kan uppfattas som rättvis vid fördelning av en viss typ av resurs och orättvis för en annan social resurs. Till exempel vet vi att människor vanligen föredrar en meritbaserad fördelning av monetära resurser såsom pengar eller värdepapper, medan fördel- ning av socio-emotionella resurser såsom kärlek och omtanke anses vara rättvis om fördelningen är jämlik eller behovsbaserad (Martin \& Harder 1994). Vidare vet vi att ju mer partikularistisk en resurs är (det vill säga när resursens värde är beroende av relationen mellan givaren och mottagaren av resursen, till exempel kärlek) desto större är förväntningen att investeringen besvaras med samma typ av resurs. Om så inte sker tenderar vi att uppfatta utbytet som orättvist (Foa \& Stein 1980). Ett annat attribut hos resurser är deras kvantitet. Forskningen visar att knappa resurser fördelas i enlighet med merit- eller behovsprincipen. När resurser finns i överflöd blir fördelningsrättvisa antingen irrelevant eller skapas genom att tillämpa en jämlik fördelning. Vidare har man studerat betydelsen av resursens valens för hur den kan fördelas på ett rättvist sätt. Här råder det delade meningar. En forskningslinje visar att resursvalens inte påverkar resursfördelningen, det vill säga vinster och förluster fördelas på samma sätt. Denna forskning visar att preferensen för jämlikhet är större än för meritprincipen (t.ex. Griffith 1989, Utz \& Sassenberg 2002). En annan forskningslinje visar däremot att vinster eller överskott fördelas enligt jämlikhetsprincipen och förluster eller underskott $i$ enlighet med meritprincipen (t.ex. Mannix et al. 1995, Törnblom \& Ahlin 1998). Kazemi och Eek (2007) förklarade dessa motstridiga resultat med att vinster och förluster fördelas enligt olika normer/principer i den mån dessa gynnar olika typer av kollektiva mål (se diskussionen om fördelningsmål tidigare i detta avsnitt). 


\section{Procedurrättvisa}

All resursfördelning innefattar två huvudsakliga aspekter: distribution och procedur. Medan den distributiva aspekten (fördelningsrättvisa) handlar om slutresultatet av en fördelning, dvs. att den mängd som var och en får är rättvis och att de resurser som distribueras är av rätt sort, kan proceduren betraktas som det sätt på vilket detta slutresultat åstadkoms. Leventhal (1980) definierade procedurrättvisa i termer av sex olika regler: konsekvens som innebär att man behandlas lika oavsett tid och rum; fördomsfrihet som innebär att beslutsfattare avstår från fördomsfulla eller egennyttiga beslut; allsidighet som innebär att beslutsfattare/makthavare tar hänsyn till all befintlig för beslutet relevant information; korrigerbarhet som innebär att det finns en möjlighet för individen att begära en oberoende omprövning av ett visst beslut; representativitet som innebär att personer som berörs av ett visst beslut bör vara med och ge sin syn på saken alternativt påverka beslutet; och etik som innebär att besluten är förenliga med gängse moraliska principer i samhället. Tyler (2000) förenklar Leventhal's resonemang och pekar på fyra faktorer: deltagande, neutralitet, tillit till beslutsfattare och behandling med respekt. Alltså är det viktigt att beslutsfattare ser till att medborgare/anställda/elever är representerade i olika organ/nämnder och kan ventilera sina åsikter. Forskningen visar att om man ges möjlighet att uttrycka sin åsikt i en fråga så uppfattar man situationen som rättvis även om man inte kan påverka de beslut som fattas. Här är dock tilliten till de som fattar beslut om fördel- ningar avgörande. Om sådan tillit saknas uppfattar människor inte situationen som rättvis trots att de har deltagit och framfört sina synpunkter. Det är alltså viktigt att beslutsfattare är ärliga när de förklarar sina avsikter och att de gör troligt att de är opartiska. Slutligen är det viktigt att människor behandlas med respekt. En lärare eller en chef som behandlar sina elever respektive medarbetare med respekt får dem att känna sig viktiga och bekräftade som individer. Om detta inte sker har vi en tendens att uppfatta utbytet som orättvist.

Det finns ett flertal teorier om procedural (o)rättvisa. Bland de första som vände sig mot equity-teorins (och fördelningsrättvisans) ensidiga och begränsade perspektiv var Thibaut och Walker (1975) som med sin instrumentella rättvisemodell hävdade att rättvisebedömningar påverkas av mer än bara vad och hur mycket man får. De antog att människor bryr sig om beslutsprocedurer vid resursfördelningar på grund av att kontroll är ett grundläggande mänskligt behov. Thibaut och Walker (1975) tar upp två typer av kontroll, nämligen beslutskontroll (veto eller möjlighet att påverka/förändra beslutets riktning) och processkontroll (möjlighet att uttrycka sin åsikt). Thibaut och Walker konstaterade efter en serie studier att en hög processkontroll ledde till en högre upplevd rättvisa bland parter i en konflikt trots att beslutskontrollen var obefintlig (t.ex. när en tredje part fäller den avgörande domen i en konflikt). Detta resultat var något av en paradox därför att det inte överensstämde med den etablerade idén om människan som en rationell, kalkylerande och nyttomaximerande varelse. Thibaut och Walker förklarade denna 
anomali med att människor trots allt drivs av ett upplyst egenintresse i sina rättvisebedömningar, dvs. människor uppskattar processkontroll för att de vill försäkra sig om ett fördelaktigt utfall i det långa loppet (beslutskontroll). Enligt Thibaut och Walker har alltså människor ett instrumentellt eller kontrollrelaterat intresse av rättvisa procedurer. Positiva effekter av procedurrättvisa beror med andra ord främst på att människor vill få materiella fördelar på lång sikt.

I kontrast till den instrumentella modellen står den relationella modellen. Enligt den relationella modellen uppskattar människor gruppmedlemskap därför att de via gruppen kan uppnå psykologiska fördelar såsom positiv självbild och självkänsla. Rättvisa i termer av korrekta formella beslutsprocedurer eller respektfull behandling av gruppkamrater/gruppledare är avgörande för att uppnå detta. Annorlunda uttryckt antar den relationella ansatsen att människor har ett relationellt intresse av beslutsprocedurer och av att rättvisa tillämpas, dvs. procedurer ger mer än endast långsiktig kontroll över framtida utfall (beslutskontroll). Den mest omtalade teori i detta sammanhang är "groupvalue model" (Lind \& Tyler 1988). Groupvalue model antar att människor bryr sig om rättvisa inte för att uppnå gynnsamma utfall på sikt utan för att rättvisa förmedlar identitetsrelevant information till individen. Individen kan därmed utifrån sina upplevelser av rättvisa i gruppen utvärdera sin egen position i gruppen. Om rättvisa råder enligt individen, kommer denne att känna sig som en fullvärdig och värdefull gruppmedlem. Om individen inte får en rättvis behandling tolkas detta som bristfällig bekräftelse från gruppen och individen ser sig själv som en medlem med låg status. Relationen till gruppen och dess medlemmar betraktas då inte som positiv av individen (för fördjupning och inblick i andra relationellt orienterade procedurrättviseteorier se Tyler \& Lind 1992 och Tyler \& Blader 2000).

\section{Individuella skillnader $i$ rättviseuppfattningar}

Under främst de senaste två decennierna har rättviseforskarna uppmärksammat betydelsen av individuella skillnader i tolerans eller känslighet mot moraliska normbrott och orättvisor (Huseman et al. 1987, Lovas \& Wolt 2002). Vi kommer i detta avsnitt att ta upp tre individuella egenskaper, nämligen tro på en rättvis värld, rättvisekänslighet och social värdeorientering.

En av den moderna rättviseforskningens portalgestalter, socialpsykologen Melvin Lerner (1980) antog att människor tenderar att $\mathrm{i}$ allmänhet betrakta världen som rättvis. När denna föreställning hotas använder man sig, enligt Lerner, av olika strategier för att avvärja hotet. Med utgångspunkten att världen är rättvis följer att människor får vad de förtjänar. De som lyckas i livet har med andra ord gjort sig förtjänta av sin framgång och de som misslyckas förtjänar inget bättre än att lida - en föreställning som ofta leder till skuldbeläggande av offer. Denna föreställning har en jagskyddande funktion och hänger samman med människans grundläggande behov av förutsägbarhet, kontroll 
och trygghet. Den är också starkare hos vissa individer än andra. För att mäta den används olika standardiserade instrument som innehåller frågor såsom "Jag anser att människors ansträngningar uppmärksammas och belönas", "Jag anser att människor förtjänar de belöningar och bestraffningar de får", "Jag anser att människor som drabbas av olycka har sig själva att skylla», osv. (se Lipkus 1991). För individer som vill se världen som rättvis, upplevs alltså orättvisor som ett större hot mot den egna existensen jämfört med dem som ser världen som mindre rättvis. Detta kan till exempel förklara varför samma orättvisa (som en orättvist låg löneförhöjning) slår hårdare mot den här typen av individer.

En annan viktig personlighetsvariabel av relevans för rättviseuppfattningar är rättvisekänslighet som introducerades av Schmitt et al. (1995). De antog att rättvisekänslighet bestod av fyra komponenter: frekvens (hur ofta man upplever eller känner sig vara utsatt för orättvisa), intensitet av ilska (den ilska man känner efter en orättvis fördelning/behandling), mental belastning (hur mycket man ältar en orättvis fördelning/behandling), och strafforientering (i vilken utsträckning och på vilket sätt man anser att en förövare eller den som utsätter andra för orättvisa bör bestraffas för att återställa rättvisa). Schmitt et al. (2005) utvidgade rättvisekänslighetsbegreppet genom att ta hänsyn till perspektiv, då tidigare forskning visar att bedömningar och upplevelser av rättvisa varierar som en funktion av vem som betraktar situationen - offret, förövaren, eller observatören (Mikula 1994).

En annan individuell egenskap som har intresserat rättviseforskarna under det senaste decenniet är social värdeorientering. Det vanligast förekommande måttet för att ta reda på människors sociala värdeorientering är »The triple-dominance measure of social values» (Van Lange et al. 1997) enligt vilket individer kan delas in i tre huvudsakliga kategorier: individualister, tävlingsorienterade och samarbetsorienterade. De två förstnämnda kallas för "proselfs" och den sistnämnda för "prosocials» i litteraturen. Med hjälp av testet mäts individens preferenser för olika sätt att fördela resurser mellan sig själv och en annan person. Ett individualistiskt val karaktäriseras av att individen väljer att maximera det egna utfallet (till exempel ett alternativ som ger $540 \mathrm{kr}$ till en själv och $280 \mathrm{kr}$ till den andra). Ett tävlingsorienterat val karaktäriseras också av egenintresse, men här väljs istället ett alternativ som maximerar differensen mellan vad individen får och vad den andra får (till exempel det alternativ som ger individen $480 \mathrm{kr}$ och den andra $80 \mathrm{kr}$ ). Som synes ger det tävlingsorienterade valet individen själv ett mindre utfall än det individualistiska. Ett samarbetsorienterat val innebär att maximera det gemensamma utfallet, det vill säga summan av individens och den andras utfall är större än för de individualistiska och tävlingsorienterade valen (ett exempel är att välja ett alternativ som ger individen och den andra $480 \mathrm{kr}$ vardera). Eek och Gärling (2006) fann att samarbetsorienterade individer är motiverade att åstadkomma jämlika utfall och inte nödvändigtvis en maximering av det gemensamma utfallet. 


\section{Avslutande kommentarer: trender och kontroverser}

Den empiriska forskningen inom rättvisefältet kom på allvar igång i och med Adams (1965) teori om proportionell fördelning. Denna teori betraktades vara mer kraftfull än sin föregångare, nämligen teorin om relativ deprivation (Crosby 1976, Stouffer et al. 1949). Adams teori (1965) var mycket förenklad. Den var baserad på en klassisk traditionell ekonomisk människosyn (dvs. homo economicus) och antog att människans främsta motiv var att tillgodose kort- och långsiktiga egennyttiga intressen. Allt mänskligt samspel begreppsliggjordes i termer av utbyten där målet var att åstadkomma proportionella fördelningar. Denna syn kritiserades tidigt bland andra av Deutsch (1975). Idag präglas fältet av multidimensionella perspektiv (t.ex. Törnblom 1992, Törnblom \& Vermunt 1999), vilket innebär att fördelningar kan åstadkommas på olika sätt och att de uppfattas som mer eller mindre rättvisa beroende på situationen. Man har även sedan sent 1970och tidigt 1980-tal uppmärksammat betydelsen av procedurrättvisa för människors rättvisebedömningar. Fördelnings- kontra procedurrättvisans relativa betydelse har också varit i fokus sedan 1990-talet. Allt detta har lett till en relativisering av rättvisebegreppet, då människans sätt att uppfatta och resonera kring rättvisa är de facto mycket mer komplicerat än vad de tidiga teorierna gjorde gällande och som vi kortfattat illustrerat i denna artikel. I det följande kommer vi att ta upp kontroversiella ämnen, några viktiga trender och forskningsmetoder i samtida socialpsykologisk rättviseforskning. Vi avslutar artikeln med att kortfattat belysa rättviseområdets relevans för socialt arbete.

\section{Rättvisebegreppets dimensionalitet}

Frågan om rättvisebegreppets dimensionalitet rör dess struktur eller annorlunda uttryckt hur många olika former/typer av rättvisa som kan urskiljas. Å ena sidan talar flertalet rättviseforskare om två huvudsakliga typer av rättvisa, nämligen fördelningsoch procedurrättvisa (t.ex. Lind \& Tyler 1988, Tyler \& Lind 1992, Törnblom 1992). $\AA ̊$ andra sidan finns det metaanalyser som talar om tre respektive fyra olika typer av rättvisa (Cohen-Charash \& Spector 2001, Colquitt et al. 2001). Cohen-Charash och Spector (2001) skiljer mellan distributiv, procedural och interaktionell rättvisa, medan Colquitt (2001) och Colquitt et al. (2001) skiljer mellan distributiv, procedural, interpersonell och informationsrättvisa. Det råder således i skrivande stund oenighet bland forskare och teoretiker om hur man bör begreppsliggöra rättvisa. Interpersonell rättvisa handlar om hur rättvist auktoriteter (t.ex. chefer) eller tredje parter tillämpar en viss procedur eller fördelar en aktuell resurs. Mer konkret skulle man kunna säga att interpersonell rättvisa handlar om i vilken utsträckning beslutsfattare och auktoriteter behandlar medborgarna med respekt och i vilken mån kommunikationen dem emellan präglas av ärlighet. Informationsrättvisa handlar om hur beslut (i synnerhet negativa) förklaras och rättfärdigas samt om hur olika typer 
av förmildrande omständigheter kan framhållas för att skapa rättvisa upplevelser. Greenberg (1993) menar att interpersonell och informationsrättvisa utgör olika aspekter av interaktionell rättvisa (samspelsrättvisa).

\section{Integreringsförsö $k^{2}$}

Törnblom och Vermunt (1999) framlade en integrerad teoretisk modell (Total Fairness Model), utifrån vilken man på ett mera meningsfullt sätt kan studera rättvisa i resursfördelning. En viktig utgångspunkt i deras modell är att en resursfördelningssituation är att betrakta som en Gestalt, dvs. en meningsfull helhet bestående av tre ömsesidigt relaterade komponenter nämligen fördelning, procedur och utfallsvärde. Törnblom och Vermunt (1999 s. 42) definierar utfallsvärde som "the perceived result of the transaction of a particular positive or negative valent resource». Författarna argumenterar att ett sådant helhetsperspektiv bland annat ökar vår förståelse för varför människor använder informationen om rättvisa $i$ en viss situation heuristiskt (Lind et al. 1993). Det innebär att om det saknas information om t.ex. fördelningsrättvisa, använder individen den tillgängliga informationen (om t.ex. procedurrättvisa) för att dra slutsatser om hela situationen i termer av rättvisa. Människans kognitiva, emotionella och beteendemässiga reaktioner är enligt ett sådant syn-

2 För en genomgång av andra teoretiska och empiriska integreringsförsök se Kazemi och Törnblom (2008). sätt en funktion av såväl händelsens utfall, procedur som händelseutfallets värde för individen ifråga.

\section{Andra trenderi samtida rättviseforskning}

Den dominerande forskningslinjen syns framför allt i kända internationella och europeiska tidskrifter med en bred läsarkrets som Journal of Personality and Social Psychology, Personality and Social Psychology Bulletin, European Journal of Social Psychology och Personality and Social Psychology Review. Forskningsfynd och teoretiska verk publiceras även i rättviseforskningens egen tidskrift Social Justice Research. Mycket av rättviseforskningen görs inom ramen för organisatorisk rättvisa och kan bland annat förutom i ovan nämnda tidskrifter även läsas i Journal of Vocational Behavior, Journal of Applied Psychology, Organizational Behavior and Human Decision Processes och Human Resource Management Review för att nämna några av de viktigaste.

Rättviseforskningen har under företrädesvis det senaste decenniet börjat intressera sig för vad upplevelser av rättvisa (istället för orättvisa) kan leda till. Man har till exempel funnit att rättvisa $i$ en rad olika sociala sammanhang skapar kreativitet, förstärker ansvarskänsla och tillit, främjar frivilligt samarbete (Tyler \& Blader 2000) och leder till att konstruktiva vägar för hantering av interpersonella konflikter används (Kazemi 2007). Det finns även ett visst intresse för att studera hur människor väljer att straffa 
personer som begått någon oförrätt eller vilken typ av kompensation som krävs för att återställa rättvisan (s.k. retributiv rättvisa, Darley \& Pittman 2003). En annan trend är studier som fokuserar på sambandet mellan identitet och rättvisa (Skitka 2003). Integreringsförsök mellan i huvudsak distributiv och procedurrättvisa har också initierats som vi kortfattat illustrerat. En annan intressant forskningslinje undersöker relationen mellan emotioner och rättvisa. Forskningen visar att emotioner både föregår och följer av våra rättvisebedömningar (Johansson et al. kommande, Mullen 2007).

\section{Forskningsmetoder}

Enligt vår mening visar fältet under sin utveckling fram till idag exempel på såväl kumulering av kunskap i vissa hänseenden som reformistiska tendenser eller fokusskiften. Teorier har inte förkastats i någon popperiansk mening. Dock har de modifierats flitigt i en Lakatos-inspirerad anda. Den systematiska socialpsykologiska rättviseforskningen etablerades först i USA. Sedan 1980-talet har även den tvärkulturella forskningen inom området växt kraftigt. Mycket av denna forskning har varit inspirerad av Harry Triandis (se till exempel Triandis 1995) och Geert Hofstede (se till exempel Hofstede 1980) och lett till vissa betydande modifieringar av kunskapsbildning kring rättvisa i väst.

Många rättviseteorier och modeller existerar. En naturlig följd av detta kunskapstillstånd har varit att man söker testa dessa teoriers validitet. Detta gör att fältet i allra högsta grad är experimentellt orienterat där hypotesprövning under kontrollerade och varierande betingelser står i centrum. Dock bör det tilläggas att många av de teser som undersökts i experimentella studier har bekräftats i naturalistiska observationer (t.ex. Randall \& Mueller 1995) och fenomenologiskt orienterade studier (Clayton 1992, Mikula 1986), vilket styrker experimentella forskningsfynds ekologiska validitet. Kvalitativ forskning är oundgänglig för alla forskningsområden och socialpsykologisk forskning om rättvisa är inget undantag. Kvalitativ rättviseforskning har bidragit till praktisk verksamhetsspecifik kunskap (Deutsch 1985), teoriutveckling (Lipkus 1992, Mikula et al. 1990, Mikula \& Schlamberger 1985) och insikter i rättvisans fenomenologi (Clayton 1992, Lupfer et al. 2000, Mikula 1986).

\section{Forskningsfältets relevans för socialt arbete}

För att visa vad den socialpsykologiska rättviseforskningen kan tillföra i fråga om förståelse av social problematik och praktiskt socialt arbete vill vi börja med att ge en definition av socialt arbete. En allmän definition som antagits av IFSW och IASSW (två internationella förbund för socialt arbete) är följande:

Socialt arbete verkar för social förändring, problemlösning $i$ mänskliga relationer, för empowerment och frigörelse med syfte att främja människors välfärd. Med utgångspunkt $i$ teorier om mänskligt beteende och 
sociala system verkar socialt arbete $i$ de områden där människor samspelar med sin omgivning. Principer om mänskliga rättigheter och social rättvisa är grundläggande för socialt arbete. (Meeuwisse \& Svärd 2006 s. 45.)

En av rättviseforskningens portalgestalter, Morton Deutsch, menar att fördelningsrättvisa handlar om just hur fördelning av sociala resurser påverkar människors allmänna välfärd, något som också kan sägas vara kärnan i socialt arbete. Enligt Deutsch (1985) kommer fördelningsrättvisa i fokus när det finns ett underskott på något som har ett inneboende eller tillskrivet värde och därmed alla som önskar ha det inte kan få det (t.ex. tak över huvudet). Rättvisa blir även viktig när något som har ett negativt värde (t.ex. varsel om uppsägning) inte kan undvikas av alla.

Avslutningsvis kan följande konstateras. Något förenklat skulle man kunna säga att socialt arbete är det vetenskapliga studiet av sociala problem. Exempel på sociala problem är många. Några av vårt samhälles mest centrala problem är jämställdhet, invandrar- och minoritetsfrågor, fördelning av resurser inom vård och omsorgssektorn, diskriminering, bostadssegregation, fattigdom, och rätten till bistånd. Om vi tittar närmare på kärnan $\mathrm{i}$ dessa problem ser vi att samtliga bottnar i en rättviseproblematik. Av detta följer att socialpsykologisk teori och forskning om rättvisa är väldigt central för förståelse av sociala problem. Blennberger (2006) hävdar att socialt arbete är ett etiskt projekt och nämner social rättvisa och jämlikhet som två viktiga argument för att bedriva socialt arbete. Detta framgår även av den definition av socialt arbete som vi gav tidigare där principer om mänskliga rättigheter och rättvisa nämndes specifikt, men även begrepp som empowerment och frigörelse som är relaterad till att kunna påverka sin situation. Något som handlar om besluts- och processkontroll, det vill säga procedural rättvisa.

Vi hör väldigt ofta att det finns mycket orättvisor i samhället men när vi frågar människor vad rättvisa/orättvisa är visar sig kunskapen många gånger vara begränsad till bara en bråkdel av vad socialpsykologer lägger in i begreppet. Vi har i denna artikel visat på rättvisebegreppets komplexitet och tagit upp socialpsykologiska teorier om faktorer som påverkar människors rättviseuppfattningar, men även teorier som behandlar varför människor bryr sig om rättvisa överhuvudtaget. ${ }^{3}$

3 Kazemi och Törnblom (kommande) har identifierat tjugoåtta aspekter av eller principer för rättvisa. 


\section{Referenser}

Adams, J. S. (1965) "Inequity in social exchange». In L. Berkowitz (ed.) Advances in experimental social psychology. New York: Academic Press.

Biel A., Eek D. \& Gärling, T. (1997) „Distributive justice and willingness to pay for municipality child care». Social Justice Research, 10, pp. 63-80.

Blennberger, E. (2006) „Etik för socialt arbete». I A. Meeuwisse, S. Sunesson \& H. Swärd (red.) Socialt arbete. Stockholm: Natur och Kultur.

Brosnan, S. F. \& de Waal, F. B. M. (2003) "Monkeys reject unequal pay“. Nature, 425, pp. 297-299.

Clayton, S. D. (1992) "The experience of injustice: Some characteristics and correlates". Social Justice Research, 5, pp. 71-91.

Cohen-Charash, Y. \& Spector, P. E. (2001) „The role of justice in organizations: A meta-analysis". Organizational Behavior and Human Decision Processes, 86, pp. 278-321.

Colquitt, J. A. (2001) "On the dimensionality of organizational justice: A construct validation of a measure». Journal of Applied Psychology, 86, pp. 386-400.

Colquitt J. A., Conlon D. E., Wesson M. J., Porter C. O. L. H. \& Ng K. Y. (2001) "Justice at the millennium: A meta-analytic review of 25 years of organizational justice research". Journal of Applied Psychology, 86, pp. 425-445.

Crosby, F. (1976) "A model of egoistical relative deprivation". Psychological Review, 83, pp. 85-113.

Darley, J. M. \& Pittman, T. S. (2003) »The psychology of compensatory and retributive justice". Personality and Social Psychology Review, 7, pp. 324-336.

Deutsch, M. (1975) „Equity, equality, and need: What determines which value will be used as the basis for distributive justice?". Journal of Social Issues, 31, pp. 137-149.

Deutsch, M. (1985) Distributive justice: A socialpsychological perspective. New Haven: Yale University Press.

Eek, D. \& Gärling, T. (2006) „Prosocials prefer equal outcomes to maximizing joint out- comes". British Journal of Social Psychology, 45, pp. 321-337.

Festinger, L. (1954) "A theory of social comparison processes". Human Relations, 7, pp. 117-140.

Foa, U. G. (1971) »Interpersonal and economic resources". Science, 171, pp. 345-351.

Foa, E. B. \& Foa, U. G. (1976) „Resource theory of social exchange«. In J. W. Thibaut, J. T. Spence \& R. C. Carson (eds.) Contemporary topics in social psychology. Morristown: General Learning Press.

Foa, U. G. \& Stein, G. (1980) „Rules of distributive justice: Institution and resource influences". Academic Psychology Bulletin, 2, pp. 89-94.

Greenberg, J. (1990) „Organizational justice: Yesterday, today and tomorrow». Journal of management, 16, pp. 399-432.

Greenberg, J. (1993) „The social side of fairness: Interpersonal and informational classes of organizational justice». In R. Cropanzano (ed.) Justice in the workplace: Approaching fairness in human resource management. Hillsdale, NJ: Erlbaum.

Griffith, W. I. (1989) "The allocation of negative outcomes". In E. E. Lawler \& B. Markovsky (eds.) Advances in group processes. Greenwich, CT: JAI Press.

Hofstede, G. (1980) Cultures consequences: International differences in work-related values. Beverly Hills, CA: Sage.

Homans, G. C. (1961) Social behavior. Its elementary forms. New York: Harcourt Brace.

Huseman R. C., Hatfield J. D. \& Miles E.W. (1987) "A new perspective on equity theory: The equity sensitivity constructu. Academy of Management Review, 12, pp. 222-234.

Johansson L.-O., Caprali T. \& Gärling T. (kommande) "Managers' Tradeoffs between Equality and Efficiency: Preferences and Emotional Responses». Journal of Applied Social Psychology.

Johansson, L.-O. \& Svedsäter, H. (kommande) "Piece of cake? Allocating rewards to third parties when fairness is costly». Organizational 
Behaviour and Human Decision Processes.

Kazemi, A. (2007) "Distributive and procedural fairness promote cooperative conflict management». In K. Törnblom \& R. Vermunt (eds.) Distributive and procedural justice: Research and social applications. Hampshire, England: Ashgate Publishing Company.

Kazemi, A. \& Eek, D. (2007) „Effects of group goal and resource valence on allocation preferences in public good dilemmas". Social Behavior and Personality, 35, pp. 803-818.

Kazemi, A. \& Eek, D. (2008) „Promoting cooperation in social dilemmas via fairness norms and group goalsu. In A. Biel, D. Eek, T. Gärling \& M. Gustafsson (eds.) New issues and paradigms in research on social Dilemmas. New York: Springer.

Kazemi, A. \& Törnblom, K. (under utgivning) „Rättvist ledarskap». I A. Kazemi (red.) Välbefinnande i arbetslivet - socialpsykologiska perspektiv. Lund: Studentlitteratur.

Kazemi, A. \& Törnblom, K. (2008) "Social psychology of justice: Origins, central issues, recent developments, and future directions". Nordic Psychology, 60, pp. 209-234.

Lane, R. E. (1986) "Market justice, political justice». American Political Science Review, 80, pp. 383-402.

Lerner, M. (1980) The belief in a just world: A fundamental delusion. New York, NY: Plenum Press.

Leventhal, G. S. (1976) „Fairness in social relationsu. In J. W. Thibaut, J. T. Spence, \& R. C. Carson (eds.) Contemporary topics in social psychology. Morristown, NJ: General Learning Press.

Leventhal, G. S. (1980) „What should be done with equity theory?" In K. J. Gergen, M. S. Greenberg, \& R. H. Willis (eds.) Social exchange: Advances in theory and research. New York: Plenum.

Lind E. A., Kulik C. T., Ambrose M. \& de Vera Park M. V. (1993) »Individual and corporate dispute resolution: Using procedural fairness as a decision heuristicu. Administrative Science Quarterly, 38, pp. 224-251.

Lind, E. A. \& Tyler, T. R. (1988) The social psycho- logy of procedural justice. New York: Plenum.

Lipkus, I. M. (1991) "The construction and preliminary validation of a global belief in a just world scale and the exploratory analysis of the multidimensional belief in a just world scale". Personality and Individual Differences, 12, pp. 1171-1178.

Lipkus, I. M. (1992) "A heuristic model to explain perceptions of unjust events". Social Justice Research, 5, pp. 359-384.

Lovas, L. \& Wolt, R. (2002) "Sensitivity to injustice in the context of some personality traits". Studia Psychologica, 44, pp. 125-131.

Lupfer M. B., Weeks K. P., Doan K. A. \& Houston D. A. (2000) „Folk conceptions of fairness and unfairness". European Journal of Social Psychol ogy, 30, pp. 405-428.

Mannix E. A., Neale M. A. \& Northcraft G. B. (1995) „Equity, equality, or need? The effects of organizational culture on the allocation of benefits and burdens". Organizational Behav ior and Human Decision Processes, 63, pp. 276286.

Martin, J. \& Harder, J. W. (1994) „Bread and roses: Justice and the distribution of financial and socio-emotional rewards in organizations". Social Justice Research, 7, pp. 241-264.

Meeuwisse, A. \& Swärd, H. (2006) "Vad är socialt arbete? «I A. Meeuwisse, S. Sunesson \& H. Swärd (red.) Socialt arbete. Stockholm: Natur och Kultur.

Mikula, G. (1980) "On the role of justice in allocation decisions". In G. Mikula (ed.) Justice and Social Interaction. New York: Springer-Verlag.

Mikula, G. (1986) "The experience of injustice: Toward a better understanding of its phenomenology". In H. W. Bierhoff, R. L. Cohen \& J. Greenberg (eds.) Justice in social relations. New York: Plenum.

Mikula, G. (1994) „Perspective-related differences in interpretations of injustice by victims and victimizers: A test with close relationships». In M. J. Lerner \& G. Mikula (eds.) Entitlement and the affectional bond. New York: Plenum.

Mikula G., Petri B. \& Tanzer N. (1990) „What people regard as unjust: Types and structures

Kazemi \& Johansson: Rättvisa i fördelningen av sociala resurser... 
of everyday experiences of injustice". European Journal of Social Psychology, 20, pp. 133-149.

Mikula, G. \& Schlamberger, K. (1985) "What people think about an unjust event: Toward a better understanding of the phenomenology of experiences of injusticer. European Journal of Social Psychology, 15, pp. 37-49.

Morris, M. W. \& Leung, K. (2000) »Justice for all? Progress in research on cultural variation in the psychology of distributive and procedural justicer. Applied Psychology: An International Review, 49, pp. 100-132.

Mullen, E. (2007) »The reciprocal relationship between affect and perceptions of fairnessu. In K. Tornblom \& R. Vermunt (eds.) Distributive and procedural justice: Research and social implications. Hampshire, England: Ashgate Publishing Company.

Randall, C. S. \& Mueller, C. W. (1995) „Extensions of justice theory: Evaluations and employees' reactions in a natural setting". Social Psychology Quarterly, 58, pp. 178-194.

Schmitt M., Neumann R. \& Montada L. (1995) "Dispositional sensitivity to befallen injustice". Social Justice Research, 8, pp. 385-407.

Schmitt M., Gollwitzer M., Maes J. \& Arbach D. (2005) "Justice sensitivity: Assessment and location in the personality space». European Journal of Psychological Assessment, 21, pp. 202-211.

Skitka, L. (2003) „Of different minds: An accessible identity model of justice reasoning". Personality and Social Psychology Review, 7, pp. 286-297.

Stouffer S. A., Suchman E. A., DeVinney L. C., Star S. A. \& Williams R. A. (1949) The American soldier: Adjustments during army life. Princeton, NJ: Princeton University Press.

Thibaut, J. \& Walker, L. (1975) Procedural justice: A psychological analysis. Hillsdale, NJ: Lawrence Erlbaum.

Triandis, H. C. (1995) Individualism and collectivism. Boulder, CO: Westview Press.

Tyler, T. (2000) „Social justice: Outcome and procedure». International Journal of Psychology, 35, pp. 117-125.

Tyler, T. R. \& Blader, S. L. (2000) Cooperation in groups: Procedural justice, social identity, and behavioral engagement. Philadelphia: Psychology Press.

Tyler, T. R. \& Lind, E. A. (1992) "A relational model of authority in groups». In M. Zanna (eds.) Advances in experimental social psychology. San Diego: Academic Press.

Tyler, T. R. \& Smith, H. J. (1998) „Social justice and social movements». In D. T. Gilbert, S. T. Fiske and G. Lindzey (eds.) Handbook of social psyc. Boston: McGraw-Hill.

Törnblom, K. Y. (1992) »The social psychology of distributive justice». In K. R. Scherer (ed.) Distributive justice from an interdisciplinary perspective. Cambridge: Cambridge University Press.

Törnblom, K. Y. \& Ahlin, E. (1998) „Mode of accomplishing positive and negative outcomes: Its effects on fairness evaluations". Social Justice Research, 11, pp. 423-442.

Törnblom K. Y., Jonsson D. R. \& Foa U. G. (1985) "Nationality, resource class, and preference among three allocation rules: Sweden versus USA». International Journal of Intercultural Relations, 9, pp. 51-77.

Törnblom, K. Y. \& Vermunt, R. (1999) "An integrative perspective on social justice: Distributive and procedural fairness evaluations of positive and negative outcome allocations". Social Justice Research, 12, pp. 39-64.

Utz, S. \& Sassenberg, K. (2002) „Distributive justice in common-bond and common-identity groups". Group Processes and Intergroup Relations, 5, pp. 151-162.

Van Lange P. A. M., Otten W., De Bruin E. N. M. \& Joireman J. A. (1997) „Development of prosocial, individualistic, and competitive orientations: Theory and preliminary evidence». Journal of Personality and Social Psychology, 73, pp. 733-746.

Walster E., Berscheid E. \& Walster G.W. (1973) "New directions in equity research". Journal of Personality and Social Psychology, 25, pp. 151176.

Walster E., Walster G.W. \& Berscheid E. (1978) Equity: Theory and research. Boston: Allyn and Bacon. 


\section{Summary}

\section{Justice in the allocation of social resources $A$ review of social psychological theory and research}

This article discusses the concept of justice/fairness from a social psychological perspective. The authors begin by briefly outlining some theoretical precursors of current social psychological research on justice. Specifically, basic tenets of the theories of social comparison, relative deprivation, social exchange, and social resource are discussed. The main part of the article is devoted to an overview of theories and empirical research efforts in the areas of distributive and procedural justice. Whereas distributive justice research targets the perceived fairness of final outcome distributions pertaining to the size and nature of distributed resources, procedural justice research examines the quality of the formal and informal aspects of the procedures enacted by authorities in making outcome decisions. The article furthermore addresses individual differences in conceptions of justice by briefly discussing the concepts of belief in a just world, justice sensitivity, and social value orientation. The article ends by discussing some current trends, controversies, and research methods in social psychological inquiries of social justice. The concluding section also includes a brief note on the relevance of social psychological theory and research for social work. 